\title{
Beyond the Veil: Re-conceptualizing the Representations of Bengali Women in Ali's Brick Lane*
}

\author{
Sana Imtiaz \\ English Language Center, Bahaudin Zakariya University, Multan, Pakistan \\ Email: sanaimtiaz_7@ hotmail.com \\ Saiqa Imtiaz Asif \\ English Language Center, Bahaudin Zakariya University, Multan, Pakistan \\ Email: saiqaasif@yahoo.com
}

\begin{abstract}
Ali's novel Brick Lane is significant because of its ambivalent representation of Bengali women. Drawing from the Postcolonial studies and feminist scholarship, the paper analyses the representations of the women in the novel, as they are shaped by various cultural signifiers. The paper critiques and notes the novel's narrative practices with the particular attention paid to the gendered discourses. Comparing the alternative representation given by Ali in the novel Brick Lane, with the one found in the idiom of the colonizer, the study highlights the significance of voicing the experiences of the women of color, particularly the Muslim Bengali women, in diaspora who are reduced to the burqa-clad representations. Deconstructing the representations in the novel, it is argued that the women exercise agency in the public and private spheres of life. The study is significant as it questions the politically motivated representations of the formerly colonized women in the idiom of the colonizer, who are oppressed by their culture, concluding that the engagement of the postcolonial female writers with voicing of the experiences of the women of color has gone a long way to challenge the image of the colonizer as a savior of the colonized women.
\end{abstract}

Index Terms—Brick Lane, representations of Bengali women, veil, postcolonial literature

\section{INTRODUCTION}

The multiple representations of the women in Postcolonial fiction have always been debated among the Postcolonial critics, Feminist scholars and Cultural theorists. Ali's novel Brick Lane, published in 2004, has been hailed by the critics, for revealing the experiences of Bengali community, particularly Bengali Muslim women, living in the Brick Lane in the U.K. The protagonist, Nazneen and her sister Hasina, living in Bangladesh, who take independent decisions about their sex and family life are contrasted with the images of the plain farm women in the idiom of colonizer, internalized by the colonized. Brick Lane sparked anger among the Bengali community, who believes that the novel has misrepresented Bengali Muslim women as sex objects, oppressed by their culture, idealizing and adapting to the Western culture. The problematic representations of the women in the popular media and literature can also be seen as an attempt to tag the image of the oppressed as well as the oppressor with the women represented. Hence, the novel warrants the further analysis of its thematic conventions and characters.

The paper explores those multiple feminine representations in the novel under discussion, using the theoretical considerations of Mernissi (1987) and Mohanty (1994), arguing that the women represented in the novel, in the private and public spheres, use various strategies to exercise agency. Drawing from the Postcolonial Studies and Islamic Feminist Criticism, the paper critiques the images of the oppressed (women as a victim of shame, physical violence and sexual exploitation) highlighting the ambivalences in the representations. Consequently, the oppressed women can also be seen in the role of subjects. The paper also brings to the light, the representations of female sexuality, as they result from the process of gendering within society, under the theoretical considerations of Mernissi (1987). Commenting on the power dynamics, the study concludes with the discussion that the oppression of the women in the novel does not necessarily originate from the culture and tradition of the colonized, rather it results from the misinterpretation of the social signifiers.

\section{Motivated RePRESENTATION IN COLONIAL DisCOURSE AND PoSTCOLONIALITY}

Said (1978) believes that the Western writers are a part of the "Project of colonization" when they view and represent East from the biased lens of Imperialism, representing Orient as a place to be civilized by the Western Colonizer. The

\footnotetext{
* The title of the paper is inspired from Mernissi’s work "Beyond the Veil-Male Female Dynamics in Muslim Society” (1987)
} 
significant part of literature and writings produced as such represent the Eastern women either as a prostitute, a sex object, or a simple, passive farm woman who never questions her male counter-part. Said (1978) argues that such representations present East, frozen in time and space, a fixed monolithic reality. The identities of Eastern women are also seen as fixed, incapable of developing or having multiplicity. The Islamic identity of women has been particularly demonized, representing Islam as a symbol of sex and polygamy. Nerval (cited in Said: 1978) describes Egypt as a place which offers enormous possibilities of satisfying male sexual desires, representing Eastern women as exotic maidens.

Islamic feminists have questioned such representations, indicating that the identity of a woman as Muslim is not monolithic or fixed, rather it keeps on changing, depending on historical, cultural, geographical and local contexts. Consequently, various religious and cultural symbols keep on acquiring new meanings. The signifier of veil, for example, does not necessarily mean oppression, as seen in the Western discourse. Rather, it could be an expression of social or political empowerment, as women in Iran chose to wear veil to show political affiliation with their sisters. Moghissi (1999) points out:

"The imagery of Islam as a peculiar religion, predisposed to maltreat the female sex, seems always to have existed. No other religion has so shamelessly been the target of demonization for its gender practices and no religion has so passionately and boldly barricaded itself against outside pressures" (p. 13)

Khan (1994) notes that Islamic Feminists tend to disregard institutions of patriarchy by arguing that certain revelations or laws are imposed in response to certain critical situations. Consequently, certain discriminatory laws against women are imposed without considering the similarity between the contexts, resulting in demonization of Islam. Postcolonial female writers try to explore how scriptures are misinterpreted and how female protagonists react to such gendering. Kahf (1999) speculates on the ways in which the Muslim woman has been made an archetypical image through her representation as "a maid to be rescued" in Western literature. In such literatures, she is an object of Western Male gaze and such representations are governed by power politics. Later, Western Feminists have also contributed to the project of colonizer, by propagating similar motivated representations. Zine (2008) adds to the discussion by noting that the postcolonial writers tend to adhere to, as well as contrast with such westernized representations by using significant tropes and motifs which are given new meanings according to situations.

Bhabha believes that Postcolonial writers write from the third space of enunciation, representing hybrid identities (Ashcrof, Griffiths, Tiffin: 1995). According to him, the solution of colonization is the mimicry of the colonizer by the colonized, resulting in the similarities as well as differences between the colonizer and the colonized. Diasporic experience plays a significant role in this regard as it brings the colonized subject in close contact with the colonizer resulting in creating fluid identities among colonized.

Indian critics, particularly those constituting Subaltern Studies Group, add to the debate by exploring the dynamics, which make the brown women lose their agency. Spivak (1988) focuses on Indian woman as a sexed subaltern, and how she is silenced either by the white feminists or by the elite Indian nationalists, speaking for her resulting in her lack of representation. Mani (1987) adds to the debate by noticing that the arguments in favor of sati and against sati were drawn from "authentic texts" without acknowledging that the construction of such documents is the result of indigenous patriarchy and the experience of colonization, which results in silencing the women.

The engagement of Postcolonial Feminist critics with the representations of the women of color as "the oppressed" result in attempting to unveil the dynamics behind the exploitation of the women and the strategies used by such women to exercise agency. In this way, they challenge the motivated representations, projecting the women of color frozen in time and space.

\section{FEMININITIES IN BRICK LANE}

Identity of the women of color is not a fixed reality, rather it keeps on shifting and changing (Khan: 1994) The multiple layers of identities are created because of the multiple positioning of the women with respect to their history, nationality, religion and ethnicity. Hence, these multiple layers of identity may be contrasting and conflicting in nature. Brick Lane is significant because it unveils the dialogics and dialectics between "the self" and "the other", which shapes the consciousness of the women of color. Consequently, the "oppressed" is not necessarily a fixed identity for women, rather, they are represented in a state of resistance against patriarchal norms. Furthermore, the oppression does not stem from the Islamic culture or religion, rather it results from the power struggle within various groups in the society, which can't specifically be a feature of Eastern society only.

Mernissi (1987) mentions the concept of Chronopolitics, i.e. "a time scenario in which power is achieved through the control of intangible: the flow of signs, the circulation of information and liquid sums." She notes that in Islamic society, the women's rights are opposed by the elite fundamentalists through a control over the power of creating knowledge i.e. misinterpretation of the past. In the course of the novel, we find Chanu obsessed with the glorious past of his nation. He would see the influence of the Western society as having a corrupting influence on Muslim women. Moghissi (1999) notices that Muslim men tried to hide Muslim women from Western gaze and the inventions of Western civilization because the body of a Muslim woman symbolized Islamic culture and identity. Keeping it in a status quo reflected the protection of Islamic culture from erosion. Mrs. Islam voices the perspective of the fundamentalists when she disapproves Jorina's working in the factory on account of her mixing up with people from other nationalities: 
"Mixing up with all sorts: Turkish, English, Jewish. All sorts. I am not old fashioned, said Mrs. Islam. I do not wear burkha. I keep purdah in my mind, which is the most important thing." (p.21)

Hence, the seclusion of Bengali women results from the conflict between the colonizer and the colonized, and the desire to protect Muslim women- a symbol of Islamic culture. Chanu liked his wife "as an un spoilt girl from the village" (p.15) for the same reason. Represented as a typical mother and wife, she is shown as a subordinate to her husband for her life. "Nazneen always walked one step behind him." (p. 90)

Chanu wants to inculcate the same spirit of nationalism among his daughters to save them from the corrupting influences of the West. He wants his daughters to be able to recite from Nazar-ul-Islam, the national poet or Tagore and to learn the national anthem of Bangladesh. "A sense of history- that is what they are missing" (p.195)

Similar to the Muslim men's obsession with the past, is their obsession with the fate. Patriarchal oppression is propagated and supported by making it a myth, an undeniable fate.

"Fighting against one's Fate can weaken the blood. Sometimes, or perhaps most times, it can be fatal. (p.5)

Fate is represented as an undeniable calamity for women, a form of oppression imposed by the male counterparts; the women who react against the patriarchy are hence seen to be reacting against God and the State.

"What could not be changed must be borne. And since nothing could be changed, everything had to be borne. This principle ruled her life. It was mantra, fettles and challenge. So that, at the age of thirty four, after she had been given three children and had one taken away, when she had a futile husband and had been fated a young and demanding lover, when for the first time, she could not wait for the future to be revealed but had to make it for herself, she was startled by her own agency as an infant who waves a clenched fist and strokes itself upon the eye." (p.6)

Hasina believes that God is putting her in tests and trials, hence, He is responsible for various forms of oppression, so fate seems to be a puritanical form of correction, a series of tests by God himself. They must not be resisted. Nazneen's mother submits to the fate, a passive victim of her husband's oppression; she is hailed by her husband as belonging to the family of saints. However, she offers the only form of resistance by taking her own life when her husband marries the second time. When Nazneen is having physical relationship with Karim, she feels that for the first time, her life is controlled not by fate, but by a force greater than fate. So fate becomes a metaphor for patriarchal oppression, against which she exercises her will. Looking at the women dressed up in underwear and shirt, she feels that clothing, not the fate decides one's future. So fate becomes a metaphor of social conditioning - clothing, food and the commonly accepted behaviors, essentialized through reinforcement. Hasina kicked against the faith(p.13). Nazneen finds out that her son Raqib should be taken to a hospital. If he is left to his fate, he might not survive. Ali's representation of the concept of fate is significant here, not only because it shows how the patriarchal society approves a particular code of conduct for the women, but also because it reveals how the women react against such politically motivated systems of belief.

Hasina and her friends at the factory are also the victims of patriarchal oppression, beating and assaults. Mernissi (1987) describes that the duty of a man to correct his wife by physical beating is voiced in Koran, however, the Prophet(P.B.U.H.) reduced it to decent measures. Disciplining female sexuality through physical violence is a very common phenomenon of Muslim society. Hasina makes her husband loose his patience without meaning to.(p.42) Jorina gets beaten up by her husband for being the best worker in the factory and getting a bonus in the form of a sari.

"Foot come all big like marrow and little finger broken. Bending over her stomach give her trouble. Renu say at least you have a husband to give good beating at least you not alone. The husband say he will beat twice each day until she tell the name of the man." (p.164)

Physical beating and all other atrocities committed by the men are justified in the name of fate- an undeniable condition which has to be borne without complaining and questioning. What is significant here is the fact that the women, victimized and brutalized, stand up together in a bond of sisterhood, to fight against oppression. Hasina and her friends at the factory helped Aleya to catch up with her work when she got beaten up by her husband. "We giving Aleya our love is best thing we can give, ” Hasina commented (p.164) She also visited and took care of Monju regularly when her husband threw acid on her. The bond of affection among the oppressed gives them the courage to fight back, hence positioning them as actors in their own right.

\section{SEXUAL EXPLOITATION AND ITS REPERCUSSIONS}

Sexual exploitation of the women of color results from the class based society and its past experience of colonization which necessitated the women to earn and move out of the four walls of the home; the traditional values dissuade them to do the same. The dilemma results in sexual harassment and exploitation of the women at their workplace and domestic violence and no recognition of their labor at the hands of their husbands and families.

The class based society results in exploitation of the working class at the hands of the elites- in the case of the novel, the women are forced to be exploited to pay for their living. Mr. Chowdhury sexually exploits Hasina and pays her back by providing her shelter. Abdul walks with her, takes care of her and tries to get the benefit of the emotional support from Hasina. Ahmad, an albino, offers her the proposal of marriage only because he himself was marginalized and left out. When he gets that sense of belonging, he gets tired of Hasina and considers her polluted and unclean. Nazneen is married off to a man she does not like, by her father. Showalter (cited in Suleri: 1993) sees a loveless marriage as a legalized rape. The apparently limited choices available to the women of color, in comparison with the Western women, 
affected by developing or underdeveloped social structures, make them a coherently oppressed group in the eyes of Western feminists. Lindsay, (cited in Mohanty: 1993) sees all the women of color as economically dependents on men. She feels that prostitution is the only form of trade available for women in Africa dividing the formerly colonized into oppressor and oppressed. What she overlooks is the fact that in the social structure, men as well as women are oppressed, which brings them at the same level. Chanu fails to get a promotion because, according to him, the Britain is racist. Dr. Azad, like Nazneen, had no share in decision making about his family members. Mustafa, the rapist gets beaten up and murdered brutally. What is significant about such representations is the fact that "the self" shares the characteristics of "the other". The discourse of the colonizer disable the women of color to rise above the level of the oppressed. Hence, the historical and cultural specificities are ignored which are variable and which render the binaries of oppressor and the oppressed as fluid.

The myth of male oppression is further strengthened by attaching the concept of izzat and asmat with women. (Rahman: 2002) The social construct of "shame" results in making the body of a woman, a battleground; in this battle, the honor of the clan and the family has to be supreme. Shame is regarded as a very important social construct which results in restricting the physical mobility of women, making their rebellion against patriarchy a taboo. However, the word acquires multiple meanings according to the context, shaping the identities of women. Jorina, an independent woman in Brick lane has been shamed, because she earns for herself. So the signifier of shame is attached to the signified of economic prosperity for women. Her husband is shamed because people assumed that he cannot adhere to the typical role of bread winner for her family; his adultery has been justified as a cause of his wife's economic prosperity hence he is not shamed; rather the blame is shifted to his wife.

"Jorina has been shamed. Her husband goes to other women. She started working and everyone said he cannot feed her. Even though, he was working himself, he was shamed. And because of this, he became reckless and started going with other women. So Jorina has brought shame on them all." (p. 97)

Razia rejects the concept of shame on human and individualistic grounds:

"Will the community feed me? Will it buy football for my son?"(p.97)

Hasina living in Bangladesh suffers on account of being an independent woman. The man in love with her decides to exploit her emotionally. The administrator at the work place tells her:

"The boy admit to all. Don't tell me your shameless lie. Go before I beat shame into you." (p.169)

Shame acquires new meanings i.e. the woman's denying the word of a man is shameful. Shame is also a form of disciplinary measure for women which, if denied, should be taught through physical violence.

The concept of shame has also been used in conjunction with the representations of female sexuality as it is shaped by the interpretation of Islamic jurisprudence and diaspora.

\section{SEXUALity OF Benglai MusLim WOMEN}

Mernissi (1987) points out that in Islam, aggression like sexual desire is seen as a form of energy, which if positively used, can result in spiritual elevation of the individual. Otherwise, it can create havoc in society by disturbing its functioning. She notices that Muslim society regulates female sexuality by assuming it as active instead of passive. Imam Ghazali (cited by Mernissi: 1987), believes that the women have the most important expression of phallic sexuality i.e. ejaculation. The difference lies in the patterns of ejaculation, woman's being much slower than that of male's. The demands of female sexuality in Islamic jurisprudence are enormous and it is the duty of the husband to satisfy them. An expression of Nazneen's sexual desires is to skate with a man. She is entranced by the postures of the couple skating together; the movements as they are depicted are highly suggestive as they are quite similar to the movements during sexual intercourse.

Khuri (2001) points out that in Islamic societies, men and women have established norms of communicating sexual desires through gestures and body movements. She elaborates some of those gestures as follows:

"Leg gestures and movements may take various positions, each conveying a special meaning. Some positions are sexually arousing. In an arousing position, the legs are slightly open on the genitalia at an acute angle and the feet take the shape of a perpendicular or an obtuse angle with the tip of one foot pointing towards the other inter actor while the second lies with the stretch of his body. In this position, it looks as if one is trying to embrace the other by using the legs instead of the hands." (p.127-128)

The movements of the couple fascinated Nazneen as they were sexually arousing. She wished to skate the same way with an equally attractive man.

"A man in a very tight suit (so tight that it made his private parts stand out on display) and a woman in the skirt that did not even cover her bottom gripped each other as an invisible force hurtled them across on oval arena. The people in the audience clapped their hands together and then stopped. ..Every move they made was urgent, intense, a declaration. The woman raised one leg and rested her boot (Nazneen saw the thin blade for the first time) on the other thigh, making a triangular flag of her legs, and spun around until she would surely fall but didn't. She did not slow down. She stopped dead and flung her arms above her head as if she had conquered everything: her body, the laws of nature and the heart of tight suited man, who slid over on his knees, vowing to lay down his life for her." (p.29) 
The other expressions of her unsatisfied sexual desires are waking up at night and eating. Denied the romantic love and attachment with her husband, Nazneen is entranced by the idea of having foreplay with Karim. She is shown not only to have an active sexuality, but also deriving pleasure and self-satisfaction from her sexual experience.

"In between the sheets, in between his arms, she took her pleasure desperately, as if the executioner waited behind the door. Beyond death was the eternal fire of hell and from every touch of flesh on flesh, she wrought the strength to endure it. Though they began with a gentle embrace, tenderness could not satisfy her, nor could she stand it and into her recklessness she drew him like moth to a flame. In the bedroom, everything changed. Things became more real and things became less real. Like a sufi in a trance, a whirling dervish, she lost one identity an found another." (p.321)

The act proves to be milestone in regaining her happiness and confidence and her search of herself. In Islamic jurisprudence, satisfied sexuality results in civilization; work is the outcome of harmonious sexuality. Nazneen got the confidence to speak out about the fate of her sister, Hasina, her rape and despoliation which she refused to talk about initially with her husband. She also started enjoying her work harmoniously.

"She told him about her sister and left nothing out, beginning with Mr. Chowdhury, the landlord, the one who (Chanu had said) was respectable type. When she spoke of the rape, she named it in the village way: Hasina was robbed of her nakphool, her nose ring; and the selling of Hasina's body she did not name, saying only my sister had to stay alive, and she saw that Chanu had understood." (p.381)

Mernissi (1987) points out that there has always been a conflict between Islamic fundamentalists and the un-veiled women, who are seen as a threat in the economic hegemony of the fundamentalists. Furthermore, the love for a woman is contrasted with the love for God, a fitna which disturbs the smooth functioning of the society. Hasina's physical beauty is seen as a threat to the social fabric:

"Nazneen told her everything about Hasina and her heart shaped face, her pomegranate pink lips and liquid eyes. How everyone stared at her, women, men and children, even when Hasina was six years old. And how the older women began to say, even before she turned eleven, that such beauty could have no earthly purpose but trouble." (p.44-45)

Mr. Chowdhury considers her beauty as the cause of disruption of the smooth functioning:

"These boys like wax around a flame. They come close and they melt. How they can help this thing? It is you who must take care." (p. 165)

The bright colored dress of the woman is also seen as a potential threat to the morals of the men:

"Shahnaz say you know how people talk. If you wear bright color, they say, you asking them to look." (p.160)

Similarly, attractive female features have to be hidden by using cosmetics to ensure the smooth functioning of the society.

"Only other day, she advising again on cosmetics. She is skill in cosmetics. She have notice my lips too pink too big can look impure. Religious protest people outside gates seek out all impurities like this. Putting powder on the lips makes hide them little bit." (p.163)

Moghissi (1999) notices that the sexuality of Muslim woman is a legal possession of Umma and Islamic state. A Muslim woman is handicapped because of the fundamentalist interpretations of sacred texts, resulting in her little or no involvement in the decisions of her marriage and divorce. Mernissi(1991) postulates that the oppression in the name of Islam, seldom has anything to do with the sacred texts as interpreted in the times of Prophet (P.B.U.H) and have a lot to do with the misinterpretation of Islamic jurisprudence for achieving political and monetary gains. Exploring the politics of gendering, Mernissi (1991) further points out that there had been a strong misogynistic tendency among Islamic fundamentalists, which is actually governed by monetary gains. The similar phenomenon is observable in the case of the novel as the fundamentalists in Bangladesh are in conflict with the women working in the factory. When Hasina works in the factory, the mullahs in the area start a campaign against the women who earn for themselves, hence prove to be competitors to the men in the jobs.

"Some people make trouble outside the factory gates. They shout to us, "Here come the garment girls, choose the one you like." A mullah organize the whole entire thing. Day and night they playing religious message with loud speaker. The say it sinful for men and women working together. But they the ones sinning take God's name, give insult to us and tell lies." (p. 159)

Women like Hasina exercise agency by deciding to work and earn for themselves. They realize that economic prosperity is the solution to the patriarchal oppression:

"Working is like a cure. Some find it curse, I meaning Renu. But I do not. Sewing pass the day and I sit with friends. As actual fact, it brings true friendship and true love." (p.159)

The similar conflict exists between Razia and her husband in U.K. Her husband, a fundamentalist spends quite less on her family and sends most of his earning to imams for building up mosques. He inspects the kitchen and insists on using all the food in the kitchen before purchasing new food. He disliked his wife, an unveiled woman, who questions the patriarchal oppression. Razia fights against the hegemony of her husband by learning to speak English and getting a job. The shift from traditional roles of the women of color results directly or indirectly from the process of colonization. Mernissi (1987) notices that in the post-colonized era, the whole Muslim nation has to turn into soldiers and workers to increase the production. For this purpose, Muslim society has to grant women the equal rights which resulted in drastic changes in the authentic social institutions. The women in Brick Lane are examples of such women who are questioning the decisions and assumptions of men by demanding equal rights, in a social fabric that is affected by colonization. 
Mrs. Islam, fights against the hegemony of patriarchy by giving loans to the people and taking interest on it. She is strongly criticized by the fundamentalists for this tendency, being called the sinner who has to burn in hell. However, she is the one, who could have her own way with the men folk. What is significant is the fact that Nazneen, follows the example of Razia and tries to learn English. She is not allowed by her husband. However, she is allowed by her husband to earn through stitching when he gives up his job and has to rely on Nazneen to earn for the family. The freedom gives her the chance of coming in contact with Karim, the fundamentalist lover, with whom she gets used to of the idea of political freedom and independence. According to Mernissi (1987), one of the challenges posed by modernity is sexual anomie- a period of deep confusion and absence of norms. Through her analysis of data from Morocco, she reveals that besides the sexual segregation which stems from Moroccan code of ethics, the reality is rapidly changing because modernity encourages a close contact between sexes. Consequently, a deep confusion and guilt arises in the minds of the youth, who are involved in dating and extra-marital sex but are confused about whether the religion permits them the liberty or not. The same situation becomes visible in the course of the novel- when Nazneen and Hasina are engaged in illicit relations with men, they are overcome by the guilt of their actions, obsessed with the thought of burning in hell yet continuing to engage in extra-marital sex because of their dissatisfied family lives. Hasina runs away with the cook in the end because she is determined to look for her happiness. Skating, as already mentioned, is seen as a symbol of exercising liberty to take decisions about the self, particularly about her sexulaity. Nazneen is taken by her daughters and Razia to skate, depicting that she is going to be independent about herself in future as well.

The sexuality of the women is also used as a tool to get their own way with men folk. Mrs. Islam narrates the incident of her own village where all the women in the village made the men dig a new well for their families by denying them the sexual relations. What is noticeable about the representations of women of color is the fact that such women are objects, not the subjects in their decisions about love and marriage. Furthermore, they are determined to have happiness, satisfaction or practical gains by making independent decisions about love and sexuality. Such representations challenge the stereotypical and fixed representations of women of color who do not dare to question the decisions of their men folk.

\section{WOMEN AS SUBJECTS}

Mohanty (1994) points out that the colonial discourse has presented women in the kinship structures as victims of male violence, defining them as the passive victims, a monolithic reality, controlled sexually by men. On the contrary, postcolonial discourse presents the women of color exercising resistance against the male hegemony, implicitly as well as explicitly. Hasina knows and exercises the tactics of controlling her husband. She keeps the house in order so that she could keep on getting favors from her husband. She, along with other women emerge as the powerful women, who discuss the strategies of winning in the power dynamics; men on the other hand only react, and that too according to the expectations of women. When Hasina runs away from her first husband, to avoid being beaten up, she gets the courage by seeing a beggar woman who is crippled but she resists when she is moved against her will.

Mohanty (1994) notices that the married women are the victims of colonial process because the process of colonization and displacement has destroyed the traditional family and kinship structures. She quotes the example of Zambian women in Bemba, who were given the protection of tribal laws after the marriage. The effects of colonization has changed the traditional institution of marriage resulting in curbing the rights and the privileges offered to the women of color through the institution of marriage. Nazneen has to go to the UK after marriage because of poor economic conditions in her own village. Consequently, she is distanced from her family and the support and protection she could have from her family. The presence of the clan and biradary is considered a protection for the women of color. Mustafa, the cowman, who rapes a young girl, is beaten up and brutally killed by the men of the girl's family. Nazneen, even as a child, decides not to save him from the painful death by rolling a log under his feet when he is dangling from the tree.

Postcolonial critics notice that the oppression of the women of color result from the process of colonization. In most cases, colonization is seen as a root cause of the oppression against women of color, since it dismantled the traditional social structure of the colonized, denying women the protection against patriarchy. The battle between the colonizer and the colonized is fought on Muslim women's bodies. Suleri (1994) points out that the Islamization of Pakistan in 1980s is the result of American political and ideological support of the military dictatorship in Pakistan, which resulted in unleashing the horrors of Hudood Ordinance and other such legislatives, curbing the freedom of women. The resistance against this oppression arose in the form of Women's Action Forum, consisting of unveiled women, who are rebuked and hated by the fundamentalists. The similar phenomenon is observed in the case of the novel where Bangladeshi community living in UK is facing colonial propaganda against the customs, beliefs and values of Bengalis. Consequently, Islamic fundamentalists raise the outcry of war against modernity, trying to veil Muslim women or inculcate Nationalist ideologies in them by teaching them Bengali language and poetry. Muslim women suffer in the conflict, as they are supposed to be loyal to their national identities, which subject them to patriarchal oppression. Consequently, the women in the novel are seen to rebel against those customs and traditions which are oppressive.

The women living in Bangladesh decide to take the help from court when they find out that the teacher at the government school does not teach well: 
"The teacher is at fault, not only father. These teachers must be responsible. Only way of making them responsible is to take the whole damn lot to the court." (p.g 171)

Similarly, Shehnaz refuses to give dowry to her in-laws, a custom commonly practised in South Asian culture:

"Why should we give dowry? I am not a burden. I make money. I am the dowry." (p.g 158)

Another form of resistance is creating knowledge about the men folk. Hasina tells Nazneen about the married women who exercise various forms of liberty at night on the roof. These women smoke "secret cigarette" and are authorities in the knowledge created by their practical experiences. "The Windy Wife" knows about various forms of indigestion. "Great Disaster" predicts as to which incident is going to bring luck or misfortune. The greatest authority is the wife who knows men. That woman believes in using discursive means to control the husband from committing adultery:

"Aaah, she says, if you want your husband faithful, you must hide his tooth brush in the morning. She do always say Aaahh before everything. "A man not going another woman with smelly breath. I know men." (p. 183)

Nazneen, when confined by Chanu in the domestic spheres, tries to interpret Quran on her own. What is significant is the fact that she does not look forward to men's interpretation of Holy Quran.

"To God belongs all that the heavens and earth contain. She said it over a few times, aloud. She was composed. Nothing could bother her. Only God, if He chose to. Chanu might flap about and squawk because Dr. Azad was coming for dinner. Let him flap. To God belongs all that the heavens and earth contain.” (p.11)

A similar tendency is observable in case of Hasina who likes to write her letters in English without caring for the rules of grammar. Ashcroft, Griffith and Tiffins (1989) believed that the colonized appropriated the language of the colonizer to make it a suitable tool for their expression. Hasina, a tough fighter, used to write English without caring for grammatical errors, hence breaking free from the grammatical rules which could silence the subaltern. Nazneen, in the beginning, was silenced because of the hegemony of her husband. Later she started speaking out, deciding for herself and for her family. She also breaks free from the confines of the spatial boundary by roaming about in the streets and getting herself lost. She felt elated at the thought of communicating in English with a perfect stranger, understanding him and being understood by him. She exercised her agency by going inside a pub to use toilet and later asking for directions from a Bangladeshi restaurant.

Guha (2001) speculates about how the peasants stood up against the Colonizer and how the elite nationalists took up the role of the colonizer, silencing the subalterns. Nazneen, as a sexed subaltern had also been silenced when Chanu, a nationalist, refuses to help Hasina in Bangladesh. However, she reacts by spoiling her house chores at home, just as peasants stood up against the nationalist from within the country.

"Nazneen dropped the promotion from her prayers. The next day, she chopped two fiery red chillies and placed them, like hand grenades, in Chanu's sandwich. Unwashed socks were paired and put back in his drawer. The razor slipped when she cut his corns. Her files got mixed up when she tidied. All her chores, peasants in his princely kingdom, rebelled in turn. Small insurrections, designed to destroy the state from within."(p. 59)

Resisting against patriarchal social structures, the women in the novel are gathered together to create a bond of sisterhood. Nazneen's mother cried over the shoulder of her sister at the fate of the girl raped by Mustafa. Nazneen's aunt, a victim of her husband's brutality rejects patriarchy by refusing to go back to her husband. Amma's sister visited her and cried for the girl raped by Mustafa.

"We're just women. What can we do?"

"They know it, that's why they act as they do."

"God has made the world this way."

"I told him I will not go back." (pg. 104)

Nazneen receives the impulses of rejecting patriarchy from Hasina, living in Bangladesh:

"Whenever she received a letter from Hasina, for the next couple of days, she imagined herself an independent woman too." (p.93)

Hasina works at the factory with four of her best friends, who are together in their strategies to fight against the oppression:

"Four in my row stick like sisters. Aliya, Shehnaz, Renu and me. I tell you about them, my other sisters" (p. 157)

So the women of color stood up against patriarchal oppression with the help of each other. The bond of sisterhood is perhaps most visible in the struggle for economic prosperity on the part of women of color. Contrary to the Western representations of the women of color which present economic development and access to the labor market as the ultimate solution to all the problems of such women (Mohanty:1994), Ali tries to unveil the problematics of oppression and resistance resulting from free access to the labor market to the women of color, in variable social structures. What comes out is the fact that the Bengali women were provided security in their traditional social set up, the dismantling of it under the influence of colonization has brought economic liberty but denied them the protection against sexual harassment.

\section{DISCUSSION AND CONCLUSION}

Contrasting the image of women of color by the colonizer, Ali's female characters are quite strong and self-sufficient. Such representations are in keeping with the traditions set by the Postcolonial female writers such as Sidhwa and Suleri. Similarly, Henderson observes a heteroglossia (1993) in the writings of black women writers. She notices that they 
write from a complex social, historical and cultural positionality which renders them as entering in to dialectic of identity with mutually shared aspects of "self" with "the other". The various points of similarity in the heteroglossia of discourses produced by postcolonial women writers challenge the fixed trope of the identity of the "oppressed" for the women of color. Suleri(1993) is of the view that creating the identity the women of color only in terms of nationalism or gender politics is in contrast with the lived experiences of such women; the identities should be construed as a result of various social, political and cultural influences which do not specifically create a fixed identity. In keeping with the argument, the representations of women in the novel are emblematic of multiplicities, as they adopt different courses of action in varying situations. The choices made by the women regarding sexuality, veiling or earning encapsulate the struggle of power and dominance by the women against patriarchy. The novelist brings out that various cultural symbols of the formerly colonized nations keep on shifting meanings; the signifier of veil, for example, can be a tool of oppression as well as empowerment. Unveiling the dimensions of power dynamics between the genders, the sociocultural set up of the Bengali community is presented as largely influenced by the Colonization. The battle between the colonizer and the colonized is fought on women's bodies, necessitating women to take decisions about tackling with various forms of patriarchy. British diaspora also plays a significant role in creating hybrid identities of women of color, the mimicry of the colonizer by adopting various cultural symbols such as clothing, language and food results in creating a socio-cultural fabric different from the traditional one.

The novelist does not present British diaspora as the solution to oppression, rather she presents the various alternatives adopted by women to fight against oppression. Cultural norms and symbols in this regard do not have to be perceived as a source of oppression, rather they can be alternatively seen as a tool of empowerment. What the writer brings out through these alternate representations is the multiplicity of the ways in which such women exercise agency. A large group of Western feminists see the sexual liberty as the privilege denied to the women of color. The novelist subtly reveals that the choices made regarding sexuality, marriage or living a life of celibacy by the women of color all aim at exercising agency in the struggle of power in the various social structures. It is the politics of gendering, its impacts and repercussions that we have tried to unveil in this paper.

\section{APPENDIX GLOSSARY}

Bhaji: A dish of mixed vegetables, common in South Asia.

Biradary: The clan or the extended family.

Burqa: A long gown and head scarf used for veiling by Muslim women.

Dal: Pulses

Dervish: A Sufi Muslim, known for is poverty and austerity, similar to mendicant friars in Christianity or Hindu sadhus.

Fitna: Disruption in society.

Hudood Ordinance: A controversial law against the women imposed in Pakistan in 1980s. The law was criticized because it made no distinction between adultery and rape.

Izzat, Asmat: These words, often synonymous refer to the concept of honor prevalent in the culture of North India and Pakistan. It implies that a woman should maintain her reputation and the reputation of her family according to the accepted code of ethics. If a woman's izzat is violated by a man, the revenge is obligatory for the woman's family. If a woman exercises sexual liberty or the right to choose her husband against the wishes of her family, the act is seen as dishonoroable and often results in physical torture or murder of the woman by her family.

Kebab: Fried pieces of minced meat.

Mullahs: Islamic clergy

Purdah: Veil

Sati: The practice of a Hindu widow's cremating herself on her husband's funeral pyre in order to fulfill her true role as wife.

Sufi: A devout believer, who very often offers devotional prayers.

Umma: Muslim community

\section{REFERENCES}

[1] Aguayo, M. ( 2009). Representations of Muslim bodies in kingdom: deconstructing discourses in Hollywood. In Global Media Journal. 2.2, 41-56.

[2] Ali, S. S. (1993). Misogynistic trends in Islamic jurisprudence. In K. Naheed (ed). Women, Myth and Realitie. Lahore: Hawwa Associates. 142-158

[3] Ashcroft, B., G. Griffiths and H. Tiffin, (1989). The Empire Writes Back: Theory and Practice in Post-colonial Literatures. Ed. Terence Hawkes. London and New York: Routledge,

[4] Ashcroft, B., G. Griffiths and H. Tiffin.(1995). The Post-colonial Studies Reader. London and New York: Routledge

[5] Barthes, R. (1967). Elements of Semiology. Cape: Hill and Wang

[6] Foucault, M. (1976). History of Sexuality. Victoria: Penguin

[7] Guha, R. (2001). The prose of counter insurgency. In G. Castle (ed) Postcolonial Discourses-An Anthology. Oxford: Blackwell Publishers. 119-150 
[8] Hall, S. (1980). Encoding decoding. In S. Hall et al. Culture, Media, Language. London: Hutchinson. 128-138

[9] Hall, S. (1994).Cultural identity and diaspora. In P. Williams and L. Chrisman (ed). Colonial Discourse and Post-Colonial Theory- A Reader. London: Harvester Wheatsheaf. 392-403.

[10] Heck, M.C.(1980). The ideological dimensions of media messages. In S. Hall (ed.) Culture, Media, Language. London: Hutchinson.

[11] Henderson, M. G. (1994). Speaking in tongues: dialogics, dialectics and the black woman writer's literary tradition. In P. Williams and L. Chrisman (ed). Colonial Discourse and Post-Colonial Theory-A Reader. London: Harvester Wheatsheaf. 257267

[12] Holland, W., W. Lachiocotte and D. Skinner. (1998). Identity and Agency in Cultural Worlds. Cambridge, M.A: Harvard University Press

[13] Kahf, M. (1999).Western Representations of Muslim Women-From Termagant to Odalisque. Texas: University of Texas Press

[14] Khan, N. S. (1994). Reflections on the question of Islam and modernity. In N. S. Khan et al. (ed) Locating the SelfPerspectives on Women and Multiple Identities. Lahore: ASR Publications. 77-95

[15] Khuri, F.I. (2001). The Body in Islamic Culture. London: Saqi Books

[16] Mani, Lata. (1987). Contentious traditions: the debate on sati in colonial India. Cultural Critique 7,119-156

[17] Mama, A. (2001). Sheroes and villains: conceptualizing colonial and contemporary violence against women in Africa. In G. Castle (ed) Postcolonial Discourses-An Anthology. Oxford: Blackwell Publishers. 251-270

[18] Mernissi. F. (1987). Beyond the Veil: Male-Female Dynamics in Modern Muslim Society. Rev. ed. Bloomington, Ind.

[19] Mernissi. F. (1991). The Veil and the Male Elite- A Feminist Interpretation of Women's Rights in Islam. USA: AddisonWesley Publishing Company

[20] Moghissi, H. (1999). Feminism and Islamic Fundamentalism. London: Oxford University Press

[21] Mohanty, C. T. (1994). Under western eyes. In P. Williams and L. Chrisman (ed). Colonial Discourse and Post-Colonial Theory- A Reader. London: Harvester Wheatsheaf. 244-256.

[22] Rajan, R.S. (2001). Representing Sati: continuities and discontinuities. In G. Castle (ed) Postcolonial Discourses-An Anthology. Oxford: Blackwell Publishers. 168-189

[23] Razack, S. (2008) Casting Out: The eviction of Muslims from Western Law and Politics. Toronto: University of Toronto press

[24] Rehman, T. (2002). Language, Ideology and Power. Karachi: Oxford University Press.

[25] Said, E. (1978). Orientalism. New York: Random House

[26] Spivak, G.C. (1988). Can the subaltern speak? In Marxism and Interpretation of Culture. edited by Cary Nelson and Lawrence Grossberg.

[27] Suleri, S. (1994). Woman skin deep: feminism and the postcolonial condition. In P. Williams and L. Chrisman (ed). Colonial Discourse and Post-Colonial Theory- A Reader. London: Harvester Wheatsheaf. 244-256.

[28] Zine, J. (2008).Muslim women and politics of representation. In The American Journal of Islamic and Social Sciences. 19.4.122 Retrieved from http://i-epistemology.net/gender-studies/727-muslim-women-and-the-politics-of-representation.html on 13.10 .2010

Sana Imtiaz has been a lecturer in English Language Center, Bahaudin Zakariya University, Multan. She is currently enrolled in M.Phil. in English Program in the same University. Her areas of interest include Postcolonial literatures, gender studies and teaching language through literature.

Saiqa Imtiaz Asif is Professor and Director at English Language Center in Baha-ud-Din Zakariya University, Multan, Pakistan. She has published extensively on Socio linguistics, Discourse Analysis and ELT in leading international journals and represented Pakistan at several international conferences in the UK, USA, Tajikistan and Egypt. 